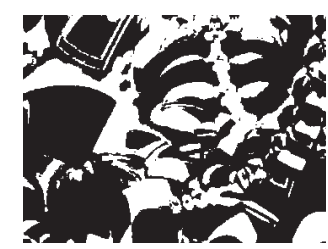

\title{
A LONGITUDINAL STUDY OF THE SOCIAL NATURE OF THE CONSTRUCT OF GIFTEDNESS IN ADULTHOOD
}

Željko RAČKI, Alma ŠKUGOR, Marija SABLIĆ Faculty of Education, Osijek

UDK: 37.011.3-051:374

Izvorni znanstveni rad

Primljeno: 4. 9. 2017.

The theoretical premises behind the three studies on giftedness in adulthood and its social nature, presented here, included the concepts of differential, ipsative and coherent stability of abilities and traits, their accessibility to valid consensual peer assessment, and their cumulative lifelong social consequences when abilities and traits are high. The studies included groups of participants attending teacher studies, students ending their studies and transitioning to work, and teachers with full range of work experience. The goal of Study 1, a longitudinal study conducted on three occasions every two years on 76 students of teacher studies transitioning to work, was to explore the predictive validity of the consensual social judgments of peer-assessed ability and creativity as the basic giftedness criteria for academic achievement, quality prospective work in education and initial career choices. The results of Study 2, with psychodiagnostic data available for 50 students of teacher studies, and Study 3, with 435 employed primary school teachers as participants, corroborated and questioned the findings of the longitudinal study. The discussion of the results followed the theoretical model of the development of giftedness across one's lifespan.

Keywords: giffedness in adulthood, giffed educator, teacher traits, teacher education, professional development

$\triangle \quad$ Željko Rački, Faculty of Education, Josip Jurai Strossmayer University of Osijek, Cara Hadrijana 10, 31000 Osijek, Croatia. E-mail: zracki@foozos.hr 
This longitudinal study of the social nature of the construct of giftedness in adulthood is of high importance as one of the very few to address giftedness in teachers. The infrequency of such studies is indicative in itself of social expectancy processes present when discussing giftedness in teachers specifically, and giftedness in educators in general. When offered data for discussion, such as the one in this study, would the general public be able to describe some teachers as gifted? This would be indicative of the ways we approach identification and nurture excellence in different work domains.

Practicing education to the point of virtuosity is akin to successful lifelong talent development described in gifted education resources. In line with this recognized commonality, the general lifespan talent development mega model (Subotnik, Olszewski-Kubilius, \& Worrell, 2011) with its developmental progression (i.e., ability, competence, expertise, eminence) discussed throughout this study, the process-based Renzulli's three-ring definition of giftedness (Renzulli, 1986) and the specific developmental model of the gifted educator (Porath, 2009; Towers \& Porath, 2001), as well as the student-identified exemplary talented teachers (Gentry, Steenbergen-Hu, \& Choi, 2011) form the theoretical bases for this study. Gifted individuals show a greater promise of the development of expertise than do non-gifted individuals. When giftedness is defined as a developing expertise (Sternberg, 2001) or a great performance (Subotnik \& Jarvin, 2005), and the creative development as the acquired expertise (Simonton, 2000) observable in education (Mikulić, Rački, \& Brajković, 2017), then a common ground is formed for the research on giftedness in beginning teachers as the developing experts.

As in any other profession, competent beginners with experience may turn into experts, and they may progress beyond expertise into eminence. Ability in teachers is a basic precondition for acquiring subject content and pedagogical knowledge. Creativity is also closely tied to giftedness (e.g., Renzulli, 1986) and education (e.g., Torrance, 1995). Accordingly, creativity can be defined as the: (a) observable, manifest, socially acceptable behavior consensually described as creative in a given social context, (b) result of the interaction of abilities, knowledge, traits, task commitment and social influences, (c) process at the end of which a person can potentially produce an observable original product (Rački, Bakota, \& Flegar, 2015). Karwowski, Kaufman, Lebuda, Szumski, \& Firkowska-Mankiewicz (2017) showed that cognitive abilities or intelligence strengthen the likelihood of creative achievement, yet high intelligence does not automatically result in it. It is nec- 
DRUŠ. ISTRAŽ. ZAGREB GOD. 27 (2018), BR. 2 STR. $261-280$

RAČKI, Ž., ŠKUGOR, A., SABLIC, M.:

A LONGITUDINAL.. essary, but not sufficient for creative achievement, for there are other factors affecting the outcomes (see Wai \& Rindermann, 2017), bringing us to the last cluster of traits present in giftedness, task commitment. When applied to teachers and teaching, it may involve active participation in continuing professional development, timely formative evaluation, and feedback, as well as active promotion of partnerships with families and community. Do gifted teachers exist, and by whom, when, and how may they be detected?

Three studies were performed in order to answer these questions. The attempt was made to cover decades of life and work within a single research project, shaping lifespan professional development into a single coherent narrative. Three studies arch the professional development in adulthood starting from university studies to the end of a teaching career and shed light on the differential, ipsative and coherent stability of psychological constructs that form giftedness, and their predictable age- and work-related developmental manifestations. Study 1 and Study 2 describe the initial intraindividual processes such as ability, creativity, and commitment as they are invested into the development of competencies. Study 3 places these in the context of professional development beliefs and practices that support the continuous investment of intraindividual processes into moving a step further by displaying leadership and organization, as well as reflective practice and innovation in education. With these three we extend beyond the longitudinal study of the social nature of the construct of giftedness in adulthood and offer a sketch of a gifted teachers' lifelong trajectory of professional development akin to talent development as it is described in giftedness studies.

\section{STUDY 1}

\section{Method}

\section{Participants}

This ongoing longitudinal study of pre-service teacher education and early teacher transition to work and postgraduate studies started in 2010 (Time 1) with a new set of data collected every two years. The data presented in this study were collected in Time 1 (2010), Time 2 (2012), and Time 3 (2014). The participants were 76 students of five-year university teacher studies in their third (Time $1 ; N=76$ ), fifth (final) year of study (Time $2 ; N=76 ; 100 \%$ ), and then again during their initial transition to work (Time $3 ; n=40 ; 52.63 \%$ ) as primary school teachers who teach all school subjects to children aged 6-12. The participants were middle class, educated Caucasian men $(n=3)$ and women $(n=73)$ with the age range at Time 1: 21-27. 
DRUŠ. ISTRAŽ. ZAGREB GOD. 27 (2018), BR. 2, STR. 261-280

RAČKI ž. ̌̌, ŠKUGOR, A., SABLIC, M A LONGITUDINAL...

\section{Materials and procedure}

The prototype of an ideal teacher. The study in Time 1 was incorporated into regular university lectures in Educational Psychology. The participants were involved in brainstorming teacher characteristics of importance to teacher work and discussed their implications for teacher selection, education, and professional development. For clarity purposes, a not nearly exhaustive set of eight teacher characteristics was selected for further study. In the second part of the lecture, the participants were instructed to evoke memories of three teachers working in primary schools from the participants' own education experience which, in their own subjective view, exemplified a prototype of an ideal primary school teacher. With those teachers in mind, the participants rated the eight characteristics of teachers on a scale from 0 to 5 meaning not typical to highly typical of those ideal primary school teachers (i.e., communicative, creative, intelligent, wise, knowledgeable, religious, physically attractive, and wealthy), as listed in Table 1.

The peer nominations. The social judgments of characteristics, theoretically based on the hypotheses of usefulness, but not necessarily absolute accuracy of social judgment (e.g., Jussim, Harber, Crawford, Cain, \& Cohen, 2005), were used in this study (e.g., CAT - Consensual Assessment Technique; Amabile, 1996). In Time 1, in the subsequent lectures, the students were provided with a sheet of paper and asked to nominate up to three peers from their study year as exemplifying the same eight characteristics as above. The question was: Based on your experience with your study year peers, nominate up to three peers whom, based on your own subjective view, you consider typical examples of behavioral display of these characteristics. They confidentially provided up to three names each. The nominations were assigned to each participant, and the number of nominations received for those characteristics represented the study measures. The percentage of the participants with at least one peer nomination on characteristics was: communicative $(52.6 \%)$, creative $(51.3 \%)$, intelligent $(59.2 \%)$, wise $(61.8 \%)$, knowledgeable $(47.4 \%)$, religious (56.6\%), physically attractive (48.7\%), and wealthy $(26.3 \%)$. In Time 1 , and in Time 2 , they were repeatedly asked the following question, representing the dependent measure (DV; ideal teacher prototype - the preferred peer-assessed teacher traits and role-bound expertise): Remind yourself of all the peers from your study year. In your own subjective view of quality education, based on observing your peers for two years, whom of your peers would you consider an ideal future primary school teacher? This question was supplemented with a subquestion, as follows: For example, once working as teachers, whom of your peers would you prefer to entrust with teaching your own child? Nominate up to three peers on the assignment sheet. 
DRUŠ. ISTRAŽ. ZAGREB GOD. 27 (2018), BR. 2 STR. $261-280$

RAČKI, ž., ŠKUGOR, A., SABLIC, M.:

A LONGITUDINAL..
Peer nominations on participant characteristics, and the peer nominations on DV, were used in the further study, as listed in Table 2.

Due to the sensitive nature of this peer-group based study, care was taken to ensure confidentiality and anonymity of nomination results throughout the study. All the results were presented to the study participants only as group findings, and no individual participants' results were ever discussed. The nominations were used because the participants encountered each other in small groups for two consecutive study years prior to this study, during which they had the opportunity to get well acquainted, offering support to nomination validity. In Time 3 the participants had finished their teacher studies, and some were employed and working as teachers. The data were gathered online concerning their teaching experiences and work circumstances, as well as their involvement in professional in-service education and/or postgraduate studies.

\section{Results and discussion}

\begin{tabular}{|c|c|c|c|c|c|c|c|c|}
\hline \multirow{2}{*}{$\begin{array}{l}\text { (1) TABLE } 1 \\
\text { Summary of intercor- } \\
\text { relations, means, and } \\
\text { standard deviations for } \\
\text { the participants' ratings } \\
\text { of prototypicality of } \\
\text { characteristics of an } \\
\text { ideal primary school } \\
\text { teacher in Study } 1 \\
\text { Measure, Time } 1\end{array}$} & \multicolumn{8}{|c|}{$\begin{array}{l}\text { Participants' implicit theories of ideal teacher characteristics } \\
\text { The participants' implicit theories converged into a portrait of } \\
\text { an ideal primary school teacher as, in that order of means, } \\
\text { communicative, creative, intelligent, wise and knowledgeable, } \\
\text { and not as comparatively typically religious, physically attrac- } \\
\text { tive, or wealthy, as listed in Table } 1 .\end{array}$} \\
\hline & 1 & 2 & 3 & 4 & 5 & 6 & 7 & 8 \\
\hline 1 Communicative & - & & & & & & & \\
\hline 2 Creative & $0.23^{*}$ & - & & & & & & \\
\hline 3 Intelligent & 0.22 & 0.04 & - & & & & & \\
\hline 4 Wise & $0.28^{*}$ & 0.22 & $0.32^{* *}$ & - & & & & \\
\hline 5 Knowledgeable & 0.10 & $0.26^{*}$ & $0.38^{* *}$ & $0.32^{* *}$ & - & & & \\
\hline 6 Religious & 0.03 & -0.12 & $-0.27^{*}$ & -0.20 & -0.11 & - & & \\
\hline 7 Physically attractive & 0.15 & -0.07 & 0.01 & 0.06 & 0.03 & 0.16 & - & \\
\hline 8 Wealthy & -0.07 & -0.15 & -0.12 & -0.07 & -0.14 & 0.15 & $0.27^{*}$ & - \\
\hline$M^{\mathrm{a}}$ & 4.91 & 4.80 & 4.58 & 4.37 & 4.34 & 1.75 & 1.47 & 0.42 \\
\hline$S D$ & 0.29 & 0.46 & 0.64 & 0.73 & 0.64 & 1.61 & 1.40 & 0.96 \\
\hline Skew & -2.89 & -2.34 & -1.25 & -0.91 & -0.77 & 0.38 & 0.44 & 2.44 \\
\hline $\mathrm{CV}(\%)$ & 5.93 & 9.63 & 13.93 & 16.65 & 14.83 & 91.96 & 94.98 & 226.99 \\
\hline
\end{tabular}

Note. $N=76$. Potential range $0-5$; low to high. Spearman's rho was used $\left(r_{\mathrm{s}}\right)$. CV or the Relative Standard Deviation (RSD) is used here to show participant disagreement on how religious, physically attractive, and wealthy, represent characteristics of ideal primary school teachers. When presented in abstract terms (Table 1), the characteristics are rated differently than when the concrete person is in question (i.e., when a characteristic is embedded within a real person, see Table 2).

a Means are listed in size from left to right; higher mean stands for higher characteristic prototypicality. The highest mean, the one for the characteristic communicative, is outlined in the box. ${ }^{*} p<0.05,{ }^{* *} p<0.01$. 
DRUŠ. ISTRAŽ. ZAGREB GOD. 27 (2018), BR. 2, STR. 261-280

RAČKI, Ž., ŠKUGOR, A., SABLIC, M.:

A LONGITUDINAL...

(1) TABLE 2

Summary of

intercorrelations, means, and standard deviations for the number of participants peer nominations on characteristics, and the repeated dependent measure in Study 1
The last three characteristics evoked more variable responses, as can be seen from CV values, with some participants endorsing and some disputing the inclusion of these characteristics. An Intraclass correlation coefficient $($ ICC $=0.99)$ with the single measure for absolute agreement of raters at 0.78 indicates high inter-rater agreement in average given values and the order for these characteristics. Significant correlations in Table 1 point to the relationships between the ratings of the characteristics in the participant sample.

\section{Use of implicit theories in peer nominations}

The absolute number of peer nominations for an ideal future teacher at Time 1 and Time 2, with two years apart, correlated positively and significantly, $r_{\mathrm{s}}(76)=0.53, p<0.001$. This is indicative of the moderate two-year differential stability of this complex peer nomination as one of the research questions. This level of stability is in line with the expected level of differential and ipsative trait stability in people of age similar to that of the participants of this study (see Caspi, 2000).

\begin{tabular}{lllllllllllll}
\hline Measure & 1 & 2 & 3 & 4 & 5 & 6 & 7 & 8 & 9 & 10 & 11 & 12 \\
\hline
\end{tabular}

Independent variables

Time 1

$\begin{array}{llllllllllllll}\text { 1 Communicative } & - & & & & & & \\ \text { 2 Creative } & 0.35^{* *} & - & & & & & \\ \text { 3 Intelligent } & 0.34^{* *} & 0.33^{* *} & - & & & & \\ \text { 4 Wise } & 0.25^{*} & 0.34^{* *} & 0.51^{* *} & - & & & \\ \text { 5 Knowledgeable } & 0.24^{*} & 0.29^{*} & 0.60^{* *} & 0.61^{* *} & - & & \\ \text { 6 Religious } & 0.11 & 0.29^{*} & 0.15 & 0.17 & 0.24^{*} & - & \\ \text { 7 Physically attractive } & 0.19 & 0.19 & 0.17 & 0.19 & 0.19 & -0.08 & - \\ \text { 8 Wealthy } & 0.19 & 0.05 & 0.05 & 0.20 & 0.16 & 0.08 & 0.28^{*}-\end{array}$

Dependent variables

$9 \mathrm{DV}$, Time 1

$10 \mathrm{DV}$, Time 2

$11 \mathrm{DV}$, Averagea

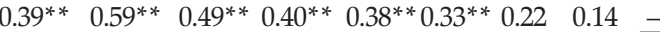

12 GPA, Time $2^{b}$

$\begin{array}{llllllllll}0.40^{* *} & 0.38^{* *} & 0.34^{* *} & 0.28^{*} & 0.17 & 0.20 & 0.27^{*} & 0.03 & 0.53^{* *}-\end{array}$

$\begin{array}{llllllllll}0.42^{* *} & 0.50^{* *} & 0.44^{* *} & 0.37^{* *} & 0.29^{*} & 0.27^{*} & 0.26^{*} & 0.06 & 0.80^{* *} & 0.91^{* *}-\end{array}$

$M$

$S D$

$0.37^{* *} 0.39^{* *} 0.51^{* *} 0.40^{* *} 0.60^{* *} 0.42^{* *} 0.06 \quad 0.25^{*} 0.52^{* *} 0.35^{* *} 0.48^{* *}-$

$\begin{array}{llllllllllll}2.89 & 2.22 & 2.51 & 2.57 & 2.47 & 2.36 & 2.38 & 2.17 & 2.95 & 2.72 & 2.83 & 4.17\end{array}$

$\begin{array}{llllllllllll}6.41 & 5.17 & 4.02 & 3.49 & 4.99 & 3.42 & 3.90 & 6.08 & 6.81 & 4.51 & 5.43 & 0.35\end{array}$

$\begin{array}{lllllllllllll}\text { C (Median) } & 1 & 0.5 & 1 & 1 & 0 & 1 & 0 & 0 & 1 & 1 & 1 & 4.14\end{array}$

$\begin{array}{lllllllllllll}\text { D (Mode) } & 0 & 0 & 0 & 0 & 0 & 0 & 0 & 0 & 0 & 0 & 0 & 3.98\end{array}$

$\begin{array}{lllllllllllll}\text { Observed range } & 0-43 & 0-36 & 0-18 & 0-15 & 0-31 & 0-14 & 0-17 & 0-30 & 0-33 & 0-25 & 0-27 & 3.16-4.85\end{array}$

Skew

$\begin{array}{llllllllllll}4.21 & 4.80 & 2.24 & 1.79 & 3.34 & 1.73 & 1.92 & 3.51 & 3.33 & 2.94 & 3.17 & -0.12\end{array}$

Note. $N=76$. Spearman's rho was used $\left(r_{\mathrm{s}}\right)$. Due to the criterion-related and expected high skew and kurtosis of consensual agreement of study participants - indicative of the convergent validity of peer nominations, but irreparable through variable transformations - the dependent and the independent variables were dichotomized for further analyses, as described in the Study 1 Method section. The retest was available for DV only. a DV, Average (Time $1+$ Time 2/2): two-occasion averaged number of peer nominations of the student as ideal future teacher, with their correlation outlined in the box to the right. The rectangle outlines the two significant predictors of DV.

b GPA was available at Time 2 for 70 participants.

${ }^{*} p<0.05,{ }^{* *} p<0.01$. 
DRUŠ. ISTRAŽ. ZAGREB GOD. 27 (2018), BR. 2 STR. $261-280$

RAČKI, ž., ŠKUGOR, A., SABLIC, M.:

A LONGITUDINAL...

FIGURE

The frequency of participants in peer nominated non-overlapping participant subgroups in Study 1 as used in regression analyses presented in Table 3
The number of students receiving reliably at least one peer nomination for an ideal future teacher on both occasions was $32(42.1 \%$ of study participants), representing the dichotomized (DV) dependent measure (nominated or not nominated).

\section{Predicting ideal future teacher peer nominations}

Because of severe skew in data, the variables were dichotomized and binary logistic regression analyses were used to predict category membership. The analyses included the dichotomized nominal dependent variable (is the student nominated both in Time 1 and in Time 2 as exemplifying an ideal teacher, with no coded as 0 or yes as 1 , and eight independent variables equally coded 0 or 1 ). The absolute number of nominations was used for all measures, with only one nomination sufficient for inclusion into nominated as, for example, communicative. Figure 1 lists the number of participants in all study subgroups.

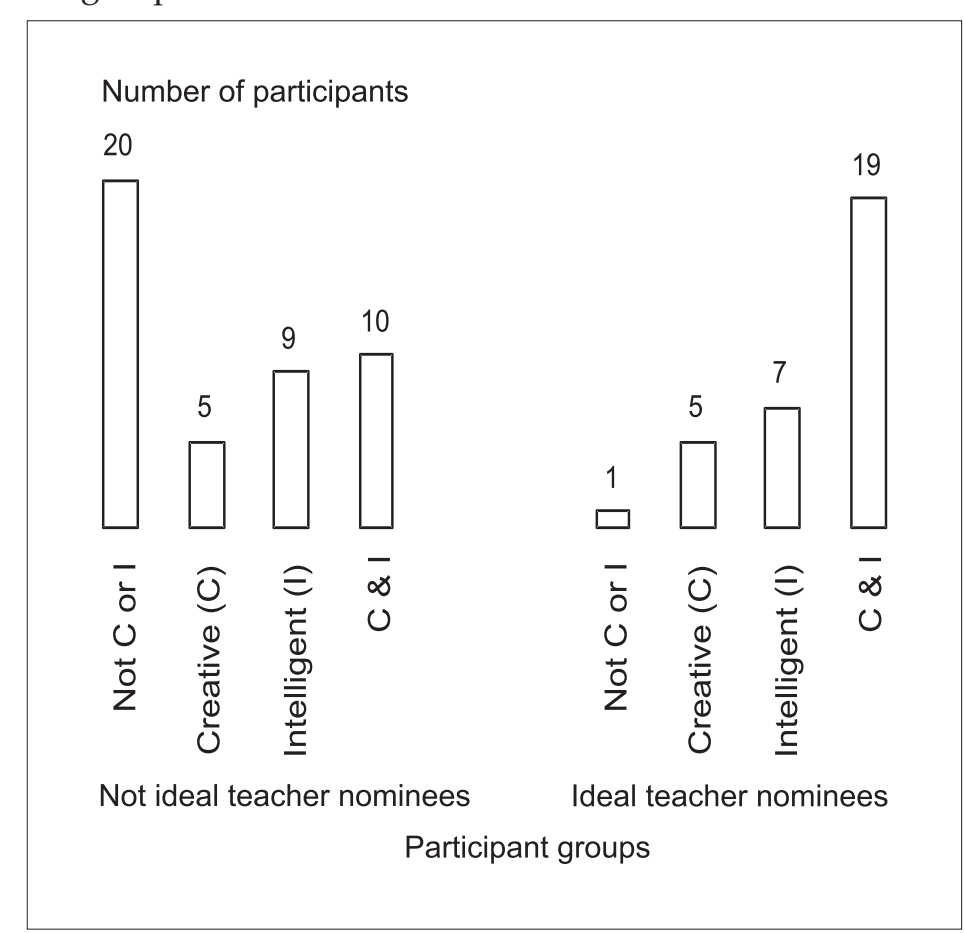

Note. $N=76$.

Model A (variable-centered, all study participants), and model B (person-centered, individual differences for two of the groups) were created and presented in Table 3 . Only two dichotomized predictors proved to be significant (student nominated as creative, and as intelligent) and distinguished nomi- 
DRUŠ. ISTRAŽ. ZAGREB GOD. 27 (2018), BR. 2, STR. $261-280$

RAČKI ž. ̌̌, ŠKUGOR, A., SABLIC, M A LONGITUDINAL... nated and not nominated students in both of the models: model $\mathrm{A}, \chi^{2}(2, N=76)=19.48, p<0.001$, and model $\mathrm{B}, \chi^{2}(1$, $n=50)=21.90, p<0.001$. The $-2 \log$ (likelihood) value for model A was 83.97, and for model B it was 45.40. Cox and Snell's $R^{2}$ indicated that in model A $22.61 \%$ of the variation in the dependent variable was explained through the use of the logistic model. Nagelkerke's $R^{2}$ was 0.304 , and indicated a significant relationship of $30.40 \%$ between the predictors and the prediction, with nonsignificant Hosmer and Lemeshow test (i.e. significance at 0.272). For model B, Cox and Snell's $R^{2}$ was $35.46 \%$ and Nagelkerke's $R^{2}$ was $47.94 \%$. The prediction success for model A, in comparison to $57.9 \%$ with the use of constant only, was $69.7 \%$ overall (77.3\% for not being nominated, and $59.4 \%$ for being nominated). For model B, the overall success was $78.0 \%$ in comparison to $60.0 \%$ with the constant only (66.7\% percent for not being nominated, and $95.0 \%$ for being nominated). Results in Table 3 suggest that when a student was nominated as creative, the odds of correct categorization increased by a factor of around 4.5 times $[\operatorname{Exp}(B)=4.39]$ when all other variables were controlled. The same applied when a student was nominated as intelligent, with similar factor increase (4.20). Being nominated as creative or as intelligent independently increased the likelihood of being nominated as an ideal future teacher in model A, without significant interaction. When the students were nominated as being both creative and intelligent (model $\mathrm{B}$ ), in comparison to the subgroup of students not having any such nominations, the odds of correct categorization increased by a factor of 38 times, which is an enormous improvement in prediction.

The GPA correlated with an average number of peer nominations for being an ideal future teacher, $r_{\mathrm{s}}(70)=0.48, p=0.001$, and most strongly with the peer assessment of being knowledgeable, $r_{\mathrm{s}}(70)=0.60, p=0.001$, as expected. Because of the significant correlations of GPA, and the number of nominations for being intelligent, $r_{\mathrm{s}}(70)=0.51, p<0.001$, and creative, $r_{\mathrm{s}}(70)=0.39, p=0.001$, as significant predictors in both model $\mathrm{A}$ and model $\mathrm{B}$, a group variable was constructed for the 70 students for whom the GPA was available with the following participant categories: not nominated (20), only creative (9), only intelligent (15), and creative and intelligent (26). A oneway analysis of variance (ANOVA) was significant, $F(3,66)=$ 9.43, MSE $=0.09, p<0.001, \eta p^{2}=0.30$, with mean GPA in the same order: $M=3.89, S D=0.30 ; M=4.11, S D=0.25 ; M=$ $4.22, S D=0.31 ; M=4.37, S D=0.32$. In line with the model $\mathrm{B}$ findings, the last group of participants in comparison to the first group had a significantly higher GPA - jointly indicative of the creative, able, as well as students motivated to achieve academically. 


\begin{tabular}{llrrrrrr}
\hline Models & Measure & $B$ & SE & Wald & $p$ & $\operatorname{Exp}(B)$ & $\begin{array}{r}95 \% \text { CI } \\
\text { of } \operatorname{Exp}(B)\end{array}$ \\
\hline A & Constant & -2.05 & 0.55 & 13.74 & 0.000 & 0.13 & \\
$\begin{array}{l}\text { Variable- } \\
\text {-centered }\end{array}$ & Creative & 1.48 & 0.54 & 7.39 & 0.007 & 4.39 & {$[1.51,12.75]$} \\
Intelligent & 1.43 & 0.58 & 6.19 & 0.013 & 4.20 & {$[1.36,12.99]$} \\
$\begin{array}{l}\text { Person- } \\
\text {-centered }\end{array}$ & Constant & -2.99 & 1.02 & 8.55 & 0.003 & 0.05 & \\
& Creative and Intelligent, in & & & & & & \\
& comparison to participants & & & & & & \\
& with no nominations on any & & & & & & \\
& of these two characteristics & 3.64 & 1.10 & 11.00 & 0.001 & 38.00 & {$[4.43,326.02]$} \\
\hline
\end{tabular}

i TABLE 3

Binary logistic regression analyses results for participants nominated as exemplifying ideal future primary school teachers compared to not nominated, by models, in Study 1
Note. Model A, $N=76$ (32 nominated and 44 not nominated as ideal future teachers). The variable interaction was not significant. Model $\mathrm{B}, n=50$ (29 nominated Creative and Intelligent, in comparison to 21 not nominated for any of the characteristics).

\section{Teachers' experiences two years} after teacher studies and into work

During follow-up in Time 3, 40 teachers decided to participate. The data were gathered regarding their teaching experiences and work circumstances, as well as their involvement in professional in-service education and/or postgraduate studies. The dummy variable indicated that the study participants in Time 3 , in comparison to the non-participants in Time 3, had a significantly higher GPA, $t(68)=-3.25, p=0.002, \eta p^{2}=0.13(M=$ $4.28 ; S D=0.36 ; M=4.02, S D=0.29$ ), and a significantly higher number of peer nominations as ideal future teachers in Time 1 and Time 2, Mann-Whitney $U(76)=449.50, z=-2.85$, $p=0.004$ (mean rank 45.26 vs. mean rank 30.99), so caution is advised in the interpretation of results. Out of these 40 participants that participated in Time 3, 19 belonged to consistently not nominated as ideal future teacher group at Time 1 and Time 2, with 9 of them employed as teachers in Time 3 (proportion or $p$ of employed is 0.47 ). Out of the remaining 21 participants consistently nominated as ideal future teachers, 17 of them were employed as teachers in Time $3(p=0.81)$. The $z$-score for the test of differences in these proportions was $z=$ $-2.22, p=0.002$. This means that a significantly higher proportion of students nominated as ideal future teachers in Time 1 and Time 2 were working as teachers in Time 3, in comparison to those not nominated.

Only three teachers in Time 3 attended Ph.D. studies of their own accord, all in Education. All were nominated in Time 1 and Time 2 as ideal future teachers, and all were currently employed as teachers. In addition to Ph.D. studies, one of them specialized in professional teacher training program, collaborating with the faculty staff on current in-service teacher 
education and educational research. In conclusion, competent (GPA), with almost twice as many working as teachers and involved in further professional development of their own accord, some of these beginning and dedicated teachers exemplify developing experts.

\section{STUDY 2}

The consensual social judgments proved to have predictive validity in Study 1 and Study 2. This fact is irrelevant if the subjective consensual peer ratings significantly departed from the objective reality of the measured abilities. Peer ratings on any trait may reflect nothing but popularity, friendships or animosities, and other constructs, respondent acquiescence, as well as other biases. The findings presented in Study 1 must be supported by at least one studied trait that was objectively measured in the participants to represent a valuable contribution to the existing body of knowledge on giftedness. Are the anticipative social judgments of prospective excellence in educational work related to the objectively measured intelligence and personality traits of the participants? Providing the answer to this question, Study 2 represents a replication of Study 1 with a new group of participants equal in age to the Study 1 participants in Time 1.

\section{Method}

\section{Participants}

The participants in 2017 were 50 students of five-year university teacher studies in their third year of study. They were middle class, educated Caucasian men $(n=3)$ and women $(n=$ 47 ) with the age range 20-33 years. One read Braille by sight, one spoke Croatian sign language, and each had a moderate to high grade point average (GPA) during their studies $(M=$ $3.99, S D=0.34$ ).

\section{Materials and procedure}

The participants gave their written consent and participated on one occasion in the study for the duration of 2.5 hours. Peer nomination procedure (DV) was similar to the one described in Study 1. The participants gave only one anonymous vote to all peers in one of two given answer forms: not yet or yes, he/she represents an ideal future primary school teacher. Out of all the received nominations, the proportion of the positive nominations that the participant received was the DV.

A measure of intelligence. The Verbal, Numeric, and Spatial ability tests used were the General Ability Tests by Smith \& Whetton (1999), in the Croatian language. The tests were obtained from the Croatian publisher and applied by the Croatian Psychological Chamber licensed psychologist in full accordance with the test manual instructions. 
Self-assessment of broad personality traits. The Croatian translation (Mlačić \& Goldberg, 2007) of the IPIP Big-Five domains questionnaire with 50 statements used for self-assessment, on a scale 1-5 meaning very inaccurate to very accurate, was used.

\begin{tabular}{|c|c|c|c|c|c|c|c|c|c|c|c|c|c|}
\hline Measure & 1 & 2 & 3 & 4 & 5 & 6 & 7 & 8 & 9 & 10 & 11 & 12 & 13 \\
\hline $\begin{array}{l}1 \text { Peer nominations } \\
\text { exemplifying ideal } \\
\text { future primary school } \\
\text { teachers (DV) }\end{array}$ & - & & & & & & & & & & & & \\
\hline $\begin{array}{l}\text { Test measures } \\
2 \text { Verbal intelligence } \\
3 \text { Numeric intelligence } \\
\text { b } \\
4 \text { Spatial intelligence }\end{array}$ & $\begin{array}{r}-0.12 \\
-0.13 \\
0.10\end{array}$ & $\begin{array}{l}- \\
0.19 \\
-0.01\end{array}$ & $\begin{array}{l}- \\
0.26\end{array}$ & - & & & & & & & & & \\
\hline $\begin{array}{l}\text { Self-assessments } \\
5 \text { Intellect } \\
6 \text { Conscientiousness } \\
7 \text { Extraversion } \\
8 \text { Agreeableness } \\
9 \text { Emotional stability }\end{array}$ & $\begin{array}{l}0.05 \\
0.37^{\text {** }} \\
0.24 \\
0.02 \\
0.15\end{array}$ & $\begin{array}{r}-0.08 \\
-0.10 \\
-0.19 \\
0.11 \\
0.21\end{array}$ & $\begin{array}{c}-0.02 \\
0.12 \\
0.12 \\
0.29^{*} \\
0.24\end{array}$ & $\begin{array}{r}-0.10 \\
-0.03 \\
-0.06 \\
0.03 \\
0.19\end{array}$ & $\begin{array}{l}- \\
0.39^{* *} \\
0.36^{*} \\
0.35^{*} \\
0.07\end{array}$ & $\begin{array}{l}- \\
0.45^{* *} \\
0.19 \\
0.41^{* *}\end{array}$ & $\begin{array}{l}- \\
0.20 \\
0.24\end{array}$ & $-\overline{0.18}$ & - & & & & \\
\hline $\begin{array}{l}10 \text { Self-assessed } \\
\text { creativity }^{\mathrm{d}} \\
11 \text { Self-assessed } \\
\text { intelligence }\end{array}$ & 0.17 & $-0.31^{*}$ & -0.01 & -0.03 & $0.54^{* *}$ & $0.47^{* *}$ & $0.40^{* *}$ & +0.16 & 0.27 & $0.56^{* *}$ & * - & & \\
\hline $\begin{array}{l}12 \mathrm{GPAf}^{\mathrm{f}} \\
13 \mathrm{CL} \text { _Finalg }\end{array}$ & $\begin{array}{l}0.40^{* *} \\
0.44^{* *}\end{array}$ & $\begin{array}{l}0.09 \\
0.20\end{array}$ & $\begin{array}{l}-0.05 \\
-0.23\end{array}$ & $\begin{array}{l}-0.02 \\
-0.14\end{array}$ & $\begin{array}{l}0.01 \\
0.02\end{array}$ & $\begin{array}{l}0.19 \\
0.18\end{array}$ & $\begin{array}{r}0.13 \\
-0.02\end{array}$ & $\begin{array}{l}-0.05 \\
-0.12\end{array}$ & $\begin{array}{l}0.23 \\
0.18\end{array}$ & $\begin{array}{l}0.15 \\
0.06\end{array}$ & $\begin{array}{r}0.07 \\
-0.09\end{array}$ & $\begin{array}{l}- \\
0.29\end{array}$ & - \\
\hline$M$ & 0.76 & 26.06 & 19.78 & 55.12 & 3.72 & 3.71 & 3.58 & 4.18 & 3.28 & 3.04 & 6.30 & 3.99 & 3.54 \\
\hline$S D$ & 0.21 & 3.09 & 5.91 & 9.94 & 0.54 & 0.67 & 0.63 & 0.41 & 0.71 & 0.62 & 0.99 & 0.34 & 0.58 \\
\hline $\begin{array}{l}\alpha \\
\text { Potential range }\end{array}$ & $\begin{array}{l}- \\
0-1\end{array}$ & $\overline{0}-36$ & $\begin{array}{l}- \\
0-36\end{array}$ & $\overline{0}-80$ & $\begin{array}{l}0.85 \\
1-5\end{array}$ & $\begin{array}{l}0.88 \\
1-5\end{array}$ & $\begin{array}{l}0.87 \\
1-5\end{array}$ & $\begin{array}{l}0.75 \\
1-5\end{array}$ & $\begin{array}{l}0.90 \\
1-5\end{array}$ & $\begin{array}{l}0.87 \\
1-5\end{array}$ & $\begin{array}{l}0.70 \\
1-9\end{array}$ & - & $\overline{2}-5$ \\
\hline Observed range & $\begin{array}{l}0.10- \\
1.00\end{array}$ & $\begin{array}{l}19- \\
32\end{array}$ & $\begin{array}{l}9- \\
31\end{array}$ & $\begin{array}{l}25- \\
74\end{array}$ & $\begin{array}{l}2.40- \\
4.70\end{array}$ & $\begin{array}{l}2.10- \\
4.80\end{array}$ & $\begin{array}{r}2.20 \\
-4.70\end{array}$ & $\begin{array}{l}3.10- \\
4.90\end{array}$ & $\begin{array}{l}1.50- \\
4.90\end{array}$ & $\begin{array}{l}-1.33- \\
4.11\end{array}$ & $\begin{array}{l}4.33- \\
8.67\end{array}$ & $\begin{array}{l}3.43- \\
4.60\end{array}$ & $\begin{array}{l}-3- \\
5\end{array}$ \\
\hline Skew & -1.59 & 0.01 & 0.12 & -0.75 & -0.66 & -0.19 & -0.38 & -0.53 & -0.20 & -0.56 & 0.12 & 0.10 & 0.52 \\
\hline
\end{tabular}

(1) TABLE 4

Summary of

intercorrelations, means, and standard deviations of measures of traits of participants nominated as exemplifying ideal future primary school teachers in Study 2
Note. $N=50$. Spearman's rho was used $\left(r_{\mathrm{s}}\right)$.

$\mathrm{a}, \mathrm{b}, \mathrm{c}$ Ability tests in the General Ability Tests by Smith \& Whetton (1999).

d Self-assessed creativity included 18 items: 17 micro-domains of creative behavior, and one item on general creativity.

e Self-assessed intelligence included six items: an item each on verbal, numeric, spatial, psychomotor, and audi-tory intelligence, and one item on general intelligence. f GPA was available for 44 students.

$\mathrm{g}$ The final grade in the Croatian language received at the national high school graduation exam was available for 46 participants. ${ }^{*} p<0.05,{ }^{* *} p<0.01$.

The creativity and intelligence self-assessments. The participants completed a questionnaire in which they assessed their own general creativity on a 1-5 scale (insufficient, sufficient, average, very good, excellent), and creativity in music, dance, creative writing, drama/acting/puppetry, drawing/painting, modeling/ sculpting, photography, design/fashion, cooking, research, mathematics, computer science, robotics, inventions/technical modeling, physical activities/sports, humor, and play/game-like activities; mean inter-item correlations were at 0.28 , with $\alpha=$ 0.87 . Self-assessed Intelligence included six items rated on a 
DRUŠ. ISTRAŽ. ZAGREB GOD. 27 (2018), BR. 2, STR. $261-280$

RAČKI ž. ̌̌, ŠKUGOR, A., SABLIC, M.

A LONGITUDINAL...
1-9 scale (not my advantage and strength to my advantage and strength), an item each on general, verbal, numeric, visual-spatial, psychomotor (the ability to perform body motor movements with precision, coordination, or strength), and auditory abilities (discriminating patterns in sounds and musical structure); mean inter-item correlations were at 0.30 , with $\alpha=0.70$.

\section{Results and discussion}

The grade received at the national high school graduation Croatian language exam $(\mathrm{CL}), r_{\mathrm{s}}(46)=0.44, p=0.002$, the university GPA, $r_{\mathrm{s}}(44)=0.40, p=0.008$, and conscientiousness, $r_{\mathrm{s}}(50)=0.37, p=0.008$, correlated positively and significantly with the DV, but no ability tests did. The results on the Verbal test in the sample ranged from the fifth to ninth stanine, suggesting average to above average verbal ability in all participants $(3,15,11,8$, and 13 participants). This was expected because the students of teacher studies were preselected during the study enrollment process according to their verbal achievement, truncating the variable range and the size of any following relationship in Study 2.

In the group of students $(n=16)$ who received the highest number of peer nominations as the ideal future teachers with the cutoff value of $90 \%$ of positive peer nominations supporting its criterion validity, the number of participants in the fifth to ninth stanine on the Verbal test was as follows: 1, 4, 6, 3 , and 2. One-third or six of these 16 nominees (37.5\%) scored at 90th percentile on the Verbal or Numeric test, supporting the claim of high measured intellectual ability in some of those nominated as ideal future teachers. One of the students in this group scored at 97th percentile on both the Verbal and Numeric ability test. The t-test results showed that these 16 students' Self-assessed Creativity was higher in comparison to others', $t(48)=2.11, p=0.04, \eta p^{2}=0.08(M=3.30 ; S D=0.49$; $M=2.92, S D=0.64)$, suggestive of higher creative self-efficacy beliefs. They also had a significantly higher CL grade, $t(44)=3.05$, $p=0.004, \eta p^{2}=0.17,(M=3.88 ; S D=0.62 ; M=3.37, S D=0.49)$, and higher GPAs in comparison to others, $t(42)=2.59, p=0.013$, $\eta p^{2}=0.14(M=4.16 ; S D=0.32 ; M=3.90, S D=0.32)$. The results of Study 2 for those participants who received $90 \%$ positive peer nominations point to their higher group average creative self-efficacy beliefs, high measured verbal or numeric ability in some (1/3) and average to above average verbal ability in all, as well as higher group average past (CL) and present motivation to use abilities in knowledge acquisition offered in teacher studies, as can be induced from higher GPAs. The results of other participants showed varied but lower levels of peer nominations on DV, varied GPAs, and varied abil- 
DRUŠ. ISTRAŽ. ZAGREB GOD. 27 (2018), BR. 2 STR. $261-280$

RAČKI, Ž., ŠKUGOR, A., SABLIC, M.:

A LONGITUDINAL.. ity levels. No retest data was available on any of the measures gathered in Study 2, so caution in interpretation is required. The common finding for those with positive peer nominations is the presence of willingness to learn (i.e., acquire knowledge) throughout the study period. The results are listed in Table 4.

This may be stable and extend into sustained lifelong career development and therefore be observed in the differences regarding positive professional development beliefs and practices in relation to the achieved and recognized professional teacher status. Study 3 aimed to put that logic to test.

\section{STUDY 3}

\section{Method}

\section{Participants}

The participants in 2016 were primary school teachers $(N=438)$ working in urban $(60 \%)$, suburban $(3.7 \%)$ or rural primary schools (36.3\%). The sample included 16 men (3.7\%), and 422 women $(96.3 \%), \chi^{2}(1, N=438)=376.34, p<0.001$. The participants had Mage $=45.1$ years $(S D=10.3$; age range: $24-65)$ and taught full-time in grades $1-4$ (children's age range: 6-10). Less than one-fifth $(n=82 ; 18.7 \%)$ were promoted to advanced vocational statuses (teacher mentors, $n=58 ; 13.2 \%$; and teacher advisors, $n=24 ; 5.5 \%$; Mage $=48.1$ years, $S D=7.05$; age range: $35-65)$.

\section{Materials and procedure}

The participants provided demographics and made self-ratings in a professional development questionnaire containing 11 questions on a seven-point scale, with 1 meaning never, and 7 meaning always, with $\alpha=0.84$. The questions that were used were formulated according to the document Competent educators of the 21st century - ISSA Definition of Quality Pedagogy (hereinafter mentioned as ISSA's Definition of Quality), published by the International Step by Step Association (ISSA), and used with permission by the Croatian publisher. The document was created to help educators focus on the salient indicators of quality in seven areas of educators' work: 1 . Interactions, 2. Family and community, 3. Inclusion, diversity, and values of democracy, 4. Assessment and planning, 5 . Teaching strategies, 6. Learning environment, and 7. Professional development (Tankersley, Brajković, \& Handžar, 2012; Tankersley, Brajković, Handžar, Rimkiene, Sabaliaskiene, Trikić, \& Vonta, 2012). The focus of this study was placed on indicators of quality practice and step forward indices in the focus area of Professional development, available in full in these publications. The participants were debriefed immediately following the study, in line with research ethics. 


\section{Results and discussion}

Three participants were removed $(0.68 \%)$ from the sample as multivariate outliers, resulting in 435 cases available for further study. Out of all the questions used in this study, two components accounted for $50.48 \%$ of the common variance. The first component had five items descriptive of teachers involved in leadership and organization activities in education, thus named Leadership and Organization, with $\alpha$ at 0.79 . The second component numbered six items (saturations $\geq 0.5$ ) descriptive of teachers involved in reflective educational practice and innovation activities, thus named Reflective Practice and Innovation, with $\alpha$ at 0.76 . Based on the congruence coefficient at +0.97 for the first extracted component, and +0.93 for the second component, the structural equivalence of this solution was supported in subsamples of teachers with advanced status in comparison to others. Linear combinations of items were formed for both components, and they correlated positively, $r(435)=0.56, p<0.001$.

Predicting the advanced professional group membership of teachers

Two continuous $z$-transformed independent variables were used as predictors and the binary dependent variable was teacher group membership (1 or 0$)$, with 81 teachers in the first, and 292 in the second teacher group. The omnibus chi-square test was significant at $\chi^{2}(2, n=373)=35.59, p<0.001$, indicating that the predictors, as a set, reliably distinguished between teachers in the advanced professional status and those teachers who were not of such status but could have been because they had enough work experience. According to the Wald criterion, only one predictor proved to be significant at 0.001 , Leadership and Organization, and no interaction was discovered. The $-2 \log$ (likelihood) value for the model presented in Table 5 was 354.78, and Cox and Snell's $R^{2}$ indicated that 9.1\% of the variation in the dependent variable was explained through the use of the logistic model. Nagelkerke's $R^{2}$ was 0.14 , and indicated a very modest relationship of $14 \%$ between the predictors and the prediction, with nonsignificant Hosmer and Lemeshow test (i.e., significance at 0.079). The prediction success for the model, in comparison to $78.3 \%$ with the use of the constant only, was $78.8 \%$ overall $(98.3 \%$ for teachers not in the advanced professional status, and $8.6 \%$ for those in the advanced professional status group). The results in Table 5 suggest that the model is more accurate at predicting who is not of advanced professional status, than who is. By means of the use of $z$-standardized professional development beliefs and practices in teachers, the odds of correct categorization increased by a factor of approximately 2 times $[\operatorname{Exp}(B)=$ 2.19], when all other variables were controlled. 


\begin{tabular}{lrrrrrrr}
\hline Predictors of professional status & & & & & & $\begin{array}{r}95 \% \text { CI } \\
\text { of } \operatorname{Exp}(B)\end{array}$ \\
\hline Constant & $B$ & SE & Wald & $p$ & $\operatorname{Exp}(B)$ & \\
Leadership and organizationa & -1.47 & 0.15 & 101.31 & 0.000 & 0.23 & \\
Reflective practice and innovation & 0.57 & 0.17 & 11.07 & 0.001 & 1.77 & {$[1.26,2.48]$} \\
& 0.32 & 0.17 & 3.70 & 0.054 & 1.38 & {$[0.99,1.92]$} \\
Constant & & & & & & \\
Professional development beliefs and practicesb & -1.47 & 0.15 & 102.21 & 0.000 & 0.23 & \\
& 0.78 & 0.14 & 30.07 & 0.000 & 2.19 & {$[1.65,2.90]$} \\
\hline
\end{tabular}

\section{(1) TABLE 5}

Logistic regression analyses results for the prediction of advanced professional status of teachers based on their professional development beliefs and practices in Study 3
Note. $n=373$. Analyses included Advanced professional status group ( $n$ $=81$ ), in comparison to No advancement in the professional status group $(n=292)$. All variables were $z$-standardized after transformation when used in regression analyses. The variable interaction was not significant. A separate analysis was done for individual variables, and the full measure, as described in the Study 3 Method section.

a Log-transformed variable.

b Square root transformed variable.

\section{Clustering teachers according to their professional development beliefs and practices}

The independent variables were used to cluster all the teachers into discernible groups by using Ward's clustering method with squared Euclidean distance. The teachers in the advanced professional statuses clustered in the fourth cluster, printed in bold in Table 6, with $p$ at $0.71(41 / 58)$ for teacher mentors, and $p$ at $0.91(21 / 23)$ for teacher advisors. These two proportions differed, $z=-1.97, p=0.049$, suggesting closer connections between the highest obtained teacher professional status (advisor) and the correspondingly more positive professional development beliefs and practices.

\begin{tabular}{|c|c|c|c|c|c|c|}
\hline \multirow[b]{2}{*}{ Cluster } & \multirow[b]{2}{*}{ Measure $[\mathrm{a}, \mathrm{b}]$} & \multirow[b]{2}{*}{$\begin{array}{l}\text { No WE condition for } \\
\text { advanced professional status }\end{array}$} & \multicolumn{4}{|c|}{$\begin{array}{l}\text { Fulfilled WE condition for } \\
\text { advanced teacher professional status }\end{array}$} \\
\hline & & & $N A^{c}$ & $\begin{array}{l}\text { Teacher } \\
\text { Mentor }\end{array}$ & $\begin{array}{l}\text { Teacher } \\
\text { Advisor }\end{array}$ & Total \\
\hline 1 & {$[-1.39,-1.53]$, Low-Low } & 12 & 30 & 2 & 0 & 44 \\
\hline 2 & {$[0.18,-1.18]$} & 22 & 30 & 4 & 1 & 57 \\
\hline 3 & {$[-0.81,-0.28]$} & 25 & 85 & 11 & 1 & 122 \\
\hline \multirow[t]{2}{*}{4} & {$[0.71,0.79]$, High-High } & 43 & 107 & 41 & 21 & 212 \\
\hline & Total & 102 & 252 & 58 & 23 & 435 \\
\hline
\end{tabular}

D TABLE 6

Cluster analysis results for the group membership of teachers based on their professional development beliefs and practices in Study 3
Note. $N=435$. The average cluster group $z$-values of variables are shown in parentheses, with descriptive titles given for two cluster groups. Teacher Mentors and Advisors were disproportionately represented in 4th cluster (High-High), as printed in italics.

a Leadership and organization.

${ }^{b}$ Reflective practice and innovation.

c NA stands for No advancement in the professional status, and WE stands for the minimum of 11 years of Work experience in education (i.e., the Teacher advisor WE condition). 


\section{GENERAL DISCUSSION}

This study provides initial support for the usefulness of information contained in the objectively identified, and self- and peer-assessed individual traits for the acquisition of lifelong competencies and teacher professional status. Competencies and statuses (i.e., expertise, and eminence) are expected of the gifted. To paint the bigger picture, from the gifted teacher one would expect excellence, and this is where this study falls short. It did not take into account how nurturing the context was in which these teachers studied, worked, and were promoted. Excellence results from both individual competence and "smart contexts" (Barab \& Plucker, 2002). Excellence is promoted in particular social, cultural, and educational settings, of which some, as suggested by Meichenbaum \& Biemiller (1998) may represent a nurturant and resourceful environment (p. 13). Our three studies support the fact that psychological processes may provide the bases of predictive significance for the emergence of peer-assessed individual excellence (i.e., DV; ideal teacher prototype). Psychological processes (ability and personality traits) have coherent stability throughout lifelong teacher professional development resulting in the consequent expertise, and eminence in some. However, they are necessarily of limited predictive importance due to the consensual nature of the latter constructs in a given environment, more or less nurturant and resourceful. An insufficiently smart context may fail to identify and support gifted teachers, and this is open to a new study. Taking a closer look at the specifically studied individual psychological processes, our three studies present the following findings.

It is impossible to teach without communicating, so communicative had the highest mean in Table 1 as the teacher characteristic in this study as well. The results presented in Table 2 jointly suggest that communicative within the ideal teacher prototype stands for - well informed or knowledgeable, culture and norm-conscious, and wellbeing related production of authentic communications within the constraints of teacher role by a person pleasing in appearance - due to its significant and positive correlations with peer-assessed creativity, intelligence, knowledge, religiousness, physical attractiveness (see Talavas, Mavor, \& Perrett, 2016), and wisdom. Wisdom is an attribute attached to high-quality teacher performance (see Arlin, 1999). Knowledgeable (intelligent) and productive (creative) were the two defining characteristics of ideal teacher candidates, as can be seen in Table 3 . The independent predictive importance of intelligence and creativity for ideal teacher peer nominations is in line with low but positive correlations between intelligence and creativity (Kim, 2008) descriptive of the necessary-but-not-sufficient relationship between intelligence and creativity (Karwowski et al., 2017), and the findings of their 
DRUŠ. ISTRAŽ. ZAGREB GOD. 27 (2018), BR. 2 STR. $261-280$

RAČKI, ž., ŠKUGOR, A., SABLIC, M.:

A LONGITUDINAL... joint presence in people usually perceived as gifted (Renzulli, 1986). Study 2 complements these with higher conscientiousness (commitment) and higher creative self-efficacy beliefs (see Karwowski \& Lebuda, 2017). The conscientious also described themselves as more extraverted, emotionally stable, and open, as displayed in Table 4, bearing similarity to many leadership qualities (see Davis, Rimm, \& Siegle, 2014, pp. 273-290), supported by the results in Study 3. The results presented in this longitudinal study and two correlation studies are in support of education as the giftedness performance domain because some of the individuals described as ideal teacher candidates exhibited characteristics commonly associated with giftedness: ability, creativity, and task commitment, and those of advanced professional statuses, the teacher mentors, and advisors, displayed leadership qualities. Teachers who understand, creatively produce, and show interest in leadership in the sociocultural context in which the teaching unfolds, seem to orchestrate not just students' (based on whose success they are promoted) but also one's own development and professional advancement throughout their lifetime, as already described by Porath $(2009$, p. 832) in her work on gifted educator. Now it is up to the context to act smart and recognize that giftedness is present in different performance domains, with education as one, in order to fully support and provide for the lifespan development of giftedness in our teachers to its full extent, for the benefit of all.

\section{GENERAL CONCLUSIONS}

The question stated at the beginning about whether gifted teachers exist, and by whom, when and how this might be detected and supported, was answered by means of the studies on psychological processes presented here. Peers, in accordance with the social nature of the construct of giftedness in adulthood, as early as the third year of teacher studies recognize with high agreement and predictive validity, for the time-frame studied, their colleagues who show promise of the development of expertise in education. Some of them display high intelligence, some high commitment, and some high creativity. Similarly, leadership qualities emerged as the developmental progression of those teachers dedicated to lifelong learning and professional advancement, all indicative of the general giftedness processes.

\section{Limitations and implications for further research}

There are limitations inherent in this study that caution against over-generalizing the results: the relatively small number of participants and the reliance on peer nominations as measures of intraindividual teacher characteristics in the longitu- 
DRUŠ. ISTRAŽ. ZAGREB GOD. 27 (2018), BR. 2, STR. 261-280

RAČKI ž. ̌̌́, ŠKUGOR, A., SABLIC, M.

A LONGITUDINAL... circumstances in which this study took place. All the data collected within this study were based on peer nominations connected to a selected number of characteristics, which may raise concerns regarding the validity and breadth of the examined construct of giftedness in educators, as well as the structural properties of the proposed indicators and their interaction. This is, likewise, available for further study.

\section{ACKNOWLEDGEMENTS}

We wish to thank the students of teacher studies and the teachers for devoting their time to participating in this study. Without their critical approach to the teacher role and their willingness to discuss the concerns about what constitutes teacher excellence to which one should aspire, this study would not have been possible.

\section{REFERENCES}

Amabile, T. M. (1996). Creativity in context. Update to the social psychology of creativity. Boulder, CO: Westview Press Inc.

Arlin, P. K. (1999). The wise teacher: A developmental model of teaching. Theory into Practice, 38(1), 12-17. https://doi.org/10.1080/00405849909543825

Barab, S. A., \& Plucker, J. A. (2002). Smart people or smart contexts? Cognition, ability, and talent development in an age of situated approaches to knowing and learning. Educational Psychologist, 37(3), 165-182. https://doi.org/10.1207/S15326985EP3703_3

Caspi, A. (2000). The child is father of the man: Personality continuities from childhood to adulthood. Journal of Personality and Social Psychology, 78(1), 158-172. https://doi.org/10.1037/0022-3514.78.1.158

Davis, G. A., Rimm, S. B., \& Siegle, D. (2014). Leadership, affective learning, and character education. In G. A. Davis, Rimm, S. B., \& Siegle, D. (Eds.), Education of the gifted and talented (pp. 273-290). London: Pearson Education Limited.

Gentry, M., Steenbergen-Hu, S., \& Choi, B. (2011). Student-identified exemplary teachers: Insights from talented teachers. Gifted Child Quarterly, 55(2), 111-125. https://doi.org/10.1177/0016986210397830

Jussim, L., Harber, K. D., Crawford, J. T., Cain, T. R., \& Cohen, F. (2005). Social reality makes the social mind: Self-fulfilling prophecy, stereotypes, bias, and accuracy. Interaction Studies, 6(1), 85-102. https://doi. org/10.1075/is.6.1.07jus

Karwowski, M., \& Lebuda, I. (2017). Creative self-concept: A surface characteristic of creative personality. In G. J. Feist, R. Reiter-Palmon, \& J. C. Kaufman (Eds.), The Cambridge handbook of creativity and personality research (pp. 84-102). New York: Cambridge University Press. https://doi.org/10.1017/9781316228036.006

Karwowski, M., Kaufman, J. C., Lebuda, I., Szumski, G., \& Firkowska-Mankiewicz, A. (2017). Intelligence in childhood and creative achievements in middle-age: The necessary condition approach. Intelligence, 64, 36-44. https://doi.org/10.1016/j.intell.2017.07.001 
DRUŠ. ISTRAŽ. ZAGREB GOD. 27 (2018), BR. 2 STR. $261-280$

RAČKI, ž., ŠKUGOR, A., SABLIC, M.:

A LONGITUDINAL..
Kim, K. H. (2008). Meta-analyses of the relationship of creative achievement to both IQ and divergent thinking test scores. Journal of Creative Behavior, 42(2), 106-130. https://doi.org/10.1002/j.2162-6057. 2008.tb01290.x

Meichenbaum, D., \& Biemiller, A. (1998). Nurturing independent learners. Helping students take charge of their learning. Cambridge, MA: Brookline Books.

Mikulić, M., Rački, Ž., \& Brajković, S. (2017). In support of agreement on gifted teachers and education as a giftedness performance domain. Croatian Journal of Education: Hrvatski časopis za odgoj i obrazovanje, 19(3), 891-917. https://doi.org/10.15516/cje.v19i3.2381

Mlačić, B., \& Goldberg, L. R. (2007). An analysis of a cross-cultural personality inventory: The IPIP Big-Five factor markers in Croatia. Journal of Personality Assessment, 88(2), 168-177. https://doi.org/10.1080/ 00223890701267993

Porath, M. (2009). What makes a gifted educator? A design for development. In L. V. Shavinina (Ed.), International handbook on giftedness (pp. 825-837). Amsterdam: Springer. https://doi.org/10.1007/978-1-4020-61622_40

Rački, Ž., Bakota, L., \& Flegar, Ž. (2015). Word knowledge as predictive of linguistic creative behaviors. Review of Psychology, 22(1-2), 11-18. https://doi.org/10.21465/rp0022.0002

Renzulli, J. S. (1986). The three-ring conception of giftedness: A developmental model of creative productivity. In R. J. Sternberg, \& J. E. Davidson (Eds.), Conceptions of giftedness (pp. 53-92). New York: Cambridge University Press.

Simonton, D. K. (2000). Creative development as acquired expertise: Theoretical issues and an empirical test. Developmental Review, 20(2), 283-318. dhttps://doi.org/10.1006/drev.1999.0504

Smith, P., \& Whetton, C. (1999). Priručnik za testove općih sposobnosti (TOS) [General Ability Tests]. Jastrebarsko: Naklada Slap.

Sternberg, R. J. (2001). Giftedness as developing expertise: A theory of the interface between high abilities and achieved excellence. High Ability Studies, 12(2), 159-179. https://doi.org/10.1080/13598130120084311

Subotnik, R. F., \& Jarvin, L. (2005). Beyond expertise: Conceptions of giftedness as great performance. In R. J. Sternberg \& J. E. Davidson (Eds.), Conceptions of giftedness (2nd ed., pp. 343-357). New York, NY: Cambridge University Press. https://doi.org/10.1017/CBO9780511610455.020

Subotnik, R. F., Olszewski-Kubilius, P., \& Worrell, F. C. (2011). Rethinking giftedness and gifted education: A proposed direction forward based on psychological science. Psychological Science in the Public Interest, 12(1), 3-54. https://doi.org/10.1177/1529100611418056

Talavas, S. N., Mavor, K. I., \& Perrett, D. I. (2016). The influence of intelligence on the endorsement of the intelligence-attractiveness halo. Personality and Individual Differences, 95, 162-167. https://doi.org/10. 1016/j.paid.2016.02.053

Tankersley, D., Brajković, S., \& Handžar, S. (2012). Koraci prema kvalitetnoj praksi: priručnik za profesionalni razvoj učitelja razredne nastave [Steps to good practice: Handbook for the professional development of primary school teachers (1-4 grade)]. Zagreb: Pučko otvoreno učilište Korak po korak. 
DRUŠ. ISTRAŽ. ZAGREB GOD. 27 (2018), BR. 2, STR. 261-280

RAČKI, Ž., ŠKUGOR, A., SABLIC, M.: A LONGITUDINAL...
Tankersley, D., Brajković, S., Handžar, S., Rimkiene, R., Sabaliaskiene, R., Trikić, Z., \& Vonta, T. (2012). Teorija u praksi: priručnik za profesionalni razvoj učitelja razredne nastave [Theory in practice: Handbook for the professional development of primary school teachers (1-4 grade)]. Zagreb: Pučko otvoreno učilište Korak po korak.

Torrance, E. P. (1995). Insights about creativity: Questioned, rejected, ridiculed, ignored. Educational Psychology Review, 7(3), 313-322. https://doi. org/10.1007/BF02213376

Towers, E., \& Porath, M. (2001). Gifted teaching: Thought and action. Roeper Review, 23(4), 202-206, https://doi.org/10.1080/02783190109554099

Wai, J., \& Rindermann, H. (2017). What goes into high educational and occupational achievement? Education, brains, hard work, networks, and other factors. High Ability Studies, 28(1), 127-145. https://doi.org/ 10.1080/13598139.2017.1302874

\section{Longitudinalno istraživanje društvene prirode konstrukta darovitosti u odrasloj dobi}

Želiko RAČKI, Alma ŠKUGOR, Marija SABLIĆ

Fakultet za odgojne i obrazovne znanosti, Osijek

Teorijske su postavke u osnovi triju istraživanja o društvenoi prirodi konstrukta darovitosti u ovom radu sljedeće: pretpostavliena stabilnost sposobnosti i osobina i njihove strukture, njihove dostupnosti valjanoj vršnjačkoi procjeni te opažljivost kumulativnih životnih posliedica kada su sposobnosti i osobine visoke. Istraživanja su uključivala studente na sveučilišnom studiju i zaposlene osobe $u$ rasponu od početka do kraja radnoga vijeka. Cili je prvoga, longitudinalnoga istraživanja, provedenog u tri navrata svake dvije godine sa 76 sudionika, studenata sveučilišnoga učiteljskog studija, odnosno učitelja s početnim radnim iskustvima, bio istražiti prediktivnu valjanost konsenzusnih vršnjačkih procjena sposobnosti i kreativnosti kao temeljnih kriterija darovitosti za akademski uspieh, prospektivnu kvalitetu obrazovnoga rada i početne radne izbore. Rezultati drugoga istraživanja, sa psihodijagnostičkim podatcima dostupnim za 50 studenata učiteljskoga studija, kao i rezultati trećega istraživanja sa 435 zaposlenih učitelja razredne nastave, potkrjepljuju, ali i dovode u pitanje, nalaze longitudinalnoga istraživanja. Rasprava je o rezultatima pratila teorijski model razvoja darovitosti kroz životni vijek.

Ključne riječi: darovitost u odrasloj dobi, daroviti edukator, obilježja učitelja, obrazovanje učitelja, profesionalni razvoj

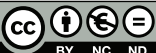

Međunarodna licenca / International License:

Creative Commons Attribution-NonCommercial-NoDerivatives 4.0. 